In his "Currency and Banking in the Province of Massachusetts Bay" Andrew McFarland Davis states that the notes issued were "based upon silver at nineteen shillings per ounce, the notes being so phrased that while they bore upon their face a value stated in coin, the promise was to pay a corresponding weight of coined silver, sterling alloy, or the value in coined standard gold." Thus it is evident that the scheme made no allowance for fluctuations in the value of silver. When the price of silver actually did rise, the natural result was a hoarding of the notes.

Horace White in his volume on "Money and Banking" aptly summarizes the results of the plan: "The details of the scheme are interesting, but the only fact of importance now is that this was an attempt to drive out a bad currency by issuing a better one to take its place. The result was in strict accordance with Gresham's Law." Rhode Island's unsound money drove the Merchants' Notes out of circulation. It is quite possible that if the boycott on Rhode Island bills had been more successful, the venture might not have failed so shortly. However, under no condition could the scheme have been long successful because of variations in the price of silver.

The Society holds the original indenture drawn up between one of the individual participating merchants and the committee of ten who sponsored the plan. In addition it possesses photostatic copies of a second similar indenture and two of the circulating notes. The photostatic copies were taken from the originals found in the records of the Massachusetts Historical Society.

\title{
On fltemoriam
}

THE Society has suffered a severe loss in the death on October $\mathrm{I} I$ of Mr. Harry R. Sinclair, a former Councilor and Vice-president of the organization. Born in Worcester in 1872 , Mr. Sinclair spent his life actively promoting the best interests of his home city. His early connection with the public schools, his graduation from the Worcester Polytechnic Institute in 1893 , and his later presidency of the Worcester Stamped Metal Company intimately bound up his career with the development of the social and business life of his city.

In February $1928 \mathrm{Mr}$. Sinclair became a member of the Society and immediately interested himself in securing a substantial sub- 
scription through which there was acquired an unusual and valuable collection of data relating to transportation. In addition to the enthusiastic cooperation which he extended to the Business Historical Society were his many local affiliations as Trustee of the Worcester Polytechnic Institute, Director of the Massachusetts Audubon Society, President of the Natural History Society, and Trustee of both the Worcester Safety Council and the Worcester Music Festival.

Mr. Sinclair served the Society for three years as a member of the Council and from I932 until the time of his death served as Vicepresident. The Society has lost a friend whose advice was always constructive and whose assistance will be sorely missed.

WITH the death of Mr. Wilmot R. Evans in July, the Society has suffered the loss of a member who has been a hearty supporter of the group's activities. Mr. Evans was a nationally known savings bank executive, serving at the time of his death as president of the Boston Five Cent Savings Bank. As head of this bank he was the third generation of Evanses to direct the institution; for his grandfather had founded the bank eighty years ago and had served forty years as president, while his father had preceded him as president.

Mr. Evans was born in Everett in 1878 , and he later attended the public schools of that place. In I 900 he was graduated from Harvard College, and in 1903 he was admitted to the practice of law following a period of study in the Boston University School of Law.

Following the lead of his father and grandfather, who had been prominent in politics as well as in banking, Mr. Evans entered the political field. He served two terms in the House of Representatives and three years in the Senate. In 1924 he was appointed United States Commissioner and was reappointed twice, beginning his third term in 1932 .

Throughout his legal and political career, Mr. Evans retained an active interest in banking as a trustee in his father's bank. When his father died in 1926 , he became president.

Since $1927 \mathrm{Mr}$. Evans has generously supported the Business Historical Society, and his constant cooperation will be greatly missed. 